\title{
Alfa 1 Antitripsin Eksikliği Olan Çocukların Karaciğer Tutulumları ve Genetik Özellikleri
}

\author{
The Liver Involvement and Genetics of Alpha-1 Antitrypsin \\ Deficiency in the Children
}

Aysel ÜNLÜSOY AKSU, Sinan SARI, Ödül EĞRiTAŞ GÜRKAN, Buket DALGIÇ

Gazi Üniversitesi Tıp Fakültesi, Çocuk Sağlığı ve Hastalıkları Anabilim Dalı, Çocuk Gastroenteroloji Bilim Dalı, Ankara, Türkiye

\section{öz}

Amaç: Alfa-1 antitripsin eksikliği (A1ATE), çocuklarda en sık görülen genetik karaciğer hastalığıdır. Çalışmamızda karaciğer disfonksiyonu bulguları ile başvuran ve A1ATE tanısı alan olguların klinik, laboratuvar ve histopatolojik bulguları incelenerek hastalığın karaciğer tutulumunun değerlendirilmesi amaçlanmıştır.

Gereç ve Yöntemler: Çocuk Gastroenteroloji kliniğinde A1ATE tanısı ile izlenen 18 yaş altındaki çocukların demografik, klinik, laboratuvar, histopatolojik bulguları ve A1ATE genotipleri geriye dönük taranmıştır. Hastalar homozigot ZZ alleline sahip olanlar (grup 1) ve diğer genotiplere sahip olanlar (grup 2) olarak ikiye ayrılarak değerlendirilmiştir.

Bulgular: Haziran 1998-Haziran 2018 yılları arasında A1ATE tanısı alan 20 çocuktan; 18'ine fenotipik inceleme yapılmış olup, 7'si homozigot ZZ (\%35), 7'si MZ (\%35), biri MS, biri $\mathrm{M}_{\text {Malton }}$, biri $\mathrm{M}_{\text {duarte, }}$, biri I allellerine sahiptir. Grup 1'de serum A1AT düzeyinin grup 2'ye göre daha düșük olduğu bulunmuștur ( $p=0,016)$. Diğer klinik ve laboratuvar bulgularına bakıldığında iki grup arasında istatistiksel anlamlı fark bulunmamıştır. İzlemde hastalardan ikisine son dönem karaciğer hastalığı nedeni ile karaciğer nakli yapılmıştır. Karaciğer nakli yapılan bir hasta MZ genotipine sahiptir, diğer hastaya genotiplendirme yapılamamıştır.

Sonuç: A1ATE çocuklarda karaciğer hastalığının önemli bir nedeni olsa da, bu mutasyonu taşıyan hastaların az bir kısmında ilerleyici karaciğer hastalığı gelişmektedir.

Anahtar Sözcükler: Alfa-1 antitripsin, Çocuklar, Fenotip, Genotip, Karaciğer, SERPINA mutasyonu

\begin{abstract}
Objective: Alpha-1 antitrypsin deficiency (AATD) is the most common genetic liver disorder in the children. We aimed to evaluate the clinical, laboratory and histopathological findings of the liver in children who referred for the liver dysfunction and diagnosed as AATD.

Material and Methods: The demographic, clinical, laboratory, histopathological findings and genotypes of the children, aged 0-18 years old and diagnosed as AATD in the department of Pediatric Gastroenterology, were evaluated retrospectively. The patients are divided into two groups as the patients who are homozygous for the ZZ allele (group 1) and the patients who have the other genotypes (group 2).

Results: The 20 children were diagnosed as AATD between June 1998 and June 2018. Phenotype or genotype tests were performed in 18 children; 7 children (35\%) were homozygous for the ZZ allele, 7 children (35\%) were heterozygous for the $Z$ allele (MZ), a child was heterozygous for the $S$ allele (MS), a child had $M_{\text {Malton }}$ allele, a child has $M_{\text {duarte }}$ allele, a child had I allele. Serum A1AT level in the group 1 was lower than the group $2(p=0,016)$. The other clinical and laboratory findings were not statistically different between the two groups. In the follow-up, liver transplantation was performed in two patients for the end-stage liver disease; one of them is heterozygous for the $Z$ allele (MZ) and the phenotype or genotype tests could not be done in the other patient
\end{abstract}

Conclusion: Although AATD is an important cause of the liver disease in children, progressive liver disease develops in a small proportion of patients carrying the AATD mutation.

Key Words: Alpha-1 antitrypsin, Children, Phenotype, Genotype, Liver, SERPINA mutation 


\section{GiRiş}

Alfa-1 antitripsin eksikliği (A1ATE), İngiliz literatüründe çocuklarda en sık görülen genetik karaciğer hastalığı olarak bildirilmektedir. $(1,2)$. Illk kez 1963 yılında tanımlanan A1ATE; en sık Kuzey Avrupa ülkelerinde görülmektedir (2). Günümüzde, dünyada çeşitli ırk ve etnik gruplarda sıklıkla bildirilmektedir (2). İnsidansı Kuzey Amerika ve Avrupa'da 1/3.8-13.4 arasında bildirilirken, Türkiye'de olgu serileri dışında insidansının belirlendiği bir yayın bulunmamaktadır (2). Dünya'da çocuklarda karaciğer naklinin en sık genetik nedeni A1ATE iken $(1,2)$, Türkiye'de Wilson hastalığı ve progresif ailesel intrahepatik kolestazlar başlıca genetik nedenleri oluşturmaktadır $(3,4)$.

A1AT nötrofil proteazları (elastaz, katepsin G, proteinaz 3) inhibe eden serin proteaz inhibitörüdür (1). Serpinler olarak adlandırılan serin-proteaz inhibitörleri ile yapısal ilişkilidir (5). Serin peptidaz inhibitör ailesi geni (SERPINA1), 14. kromozomda yer alır. A1AT varyantları asit pH'da agaroz elektroforez veya poliakrilamid ile plazma izoelektrik fokuslama yöntemi ile sınıflandırılır. Her bir fenotip; aminoasit değişikliklerine, izoelektrik fokuslamadaki geçiş hızlarına göre temel olarak M, S, Z, F olarak isimlendirilir (5). DNA dizi analizi ile de 100'den fazla allelik varyant tanımlanmıştır (1). Normal allel M'dir (M1, M2, M3). A1ATE'ne sahip olguların büyük çoğunluğu S ve Z allellerine sahiptir (2). A1AT, çoğunlukla hepatositte sentezlenen bir akut faz sekretuvar glikoproteinidir (2). Karaciğer dışında akciğer, bağırsak epitel hücrelerinde, nötrofil ve alveolar makrofajlarda da küçük bir kısmı üretilir (5). En önemli görevi akciğerde nötrofil kaynaklı elastazın neden olduğu ekstrasellüler matriks bozulmasını engellemektir (5). Yetersiz antiproteaz aktivitesine sahip A1ATE olan bireylerde mikroorganizmalar ve/veya diğer inflamatuvar uyaranlar ile nötrofil elastaz (proteaz) aktivitesi artarak akciğer dokusunun yıkımına neden olur (2). Sigara kullanımı da az miktarda olan A1AT'in oksidatif inaktivasyonuna neden olarak akciğer yıkımını arttırır (1). Antiproteaz aktivitenin kaybı ile akciğerde amfizem, kronik bronşit, kronik obstrüktif akciğer hastalığı (KOAH), bronşektazi ve astıma neden olur $(2,5)$. A1ATE olan çocuklarda, solunum fonksiyonlarında belirgin bozukluk saptanmamıştır (5).

A1ATE olan olgularda yanlış katlanan, anormal polimerize protein yapı hepatositlerde endoplazmik retikulumda birikerek karaciğer hastalığı oluşumuna neden olur (2). Karaciğer tutulumu hepatit, siroz, hepatokarsinom ve karaciğer yetmezliği olarak karşımıza çıkar (5). A1ATE olan tüm hastaların \%10'unda siroz gelişirken, A1ATE olan çocukların \%16.5'inde, yetişkinlerin \%14.7'sinde karaciğer nakil gereksinimi olduğu saptanmıştır (6). Karaciğer tutulumu en sık homozigot ZZ allelinde görülür (1). Avrupa'daki homozigot ZZ allel sıklığı \% 0.5-4 arasındadır (5). Heterozigot MZ alleli, karaciğer tutulumu açısından düşük risk taşımaktadır (7). Nadir olarak da A1ATE'de nekrotizan pannikülit ve anti nötrofilik sitoplazmik antikor (ANCA) ilişkili vaskülit görülebilir $(1,2)$.

Çalışmamızda karaciğer disfonksiyonu bulguları ile başvuran ve A1ATE tanısı alan olguların klinik, laboratuvar ve histopatolojik bulguları incelenerek hastalığın karaciğer tutulumunun değerlendirilmesi amaçlanmıştır.

\section{GEREÇ ve YÖNTEM}

Çocuk Gastroenteroloji Bilim Dalı'nda 18 yaş altında A1ATE tanısı alan hastalar çalışmaya dahil edilmiştir. Hastaların demografik bilgileri, başvuru yaşları, başvuru yakınmaları, muayenede karaciğer ve dalak büyüklükleri, karaciğer biyopsisi yapılan hastaların histopatolojik özellikleri, A1ATE fenotip ve genotipleri, izlem süreleri geriye dönük olarak, dosya ve elektronik hasta kayıtlarından taranmıştır. Hastaların tam kan sayımı, karaciğer fonksiyon testleri ve ölçülen serum A1AT düzeyleri kaydedilmiştir. Hastalar homozigot ZZ alleline sahip olanlar (grup 1) ve diğer fenotiplere sahip olanlar (grup 2) olarak ikiye ayrılarak değerlendirilmiştir. Alfa 1 AT serum düzeyleri turbidimetrik yöntem ile ölçülmüştür; normal aralığı 90-200 mg/ dl'dir.

İstatistiksel analizler, 'IBM SPSS for Windows version 21.0 Armonk, NY, ABD' paket programında yapılmıştır. Devamlı değişkenler ortanca (minimum-maksimum) olarak verilmiştir. Devamlı değişkenler Mann-Whitney U test, devamlı olmayan değişkenler Fisher exact test kullanılarak karşılaştırılmıştır. İstatistiksel olarak anlamlı p değeri <0,05 olarak kabul edilmiştir. Çalışmamıza Gazi Üniversitesi Tıp Fakültesi Etik Kurulu'ndan 2018 yılı 484 sayılı kararı ile onay alınmıştır.

\section{BULGULAR}

Çocuk Gastroenteroloji, Hepatoloji ve Beslenme bölümünde Haziran 1998-Haziran 2018 yılları arasında 20 hastaya A1ATE tanısı konulmuştur. Hastaların tanı yaşı ortalama $14.7 \pm 16.7$ ay (1-66 ay, ortanca 11 ay) olup, 14 hasta (\%70) erkektir. Hastaların 7'sinde homozigot ZZ (\%35), 7'sinde MZ (\%35), birinde MS,

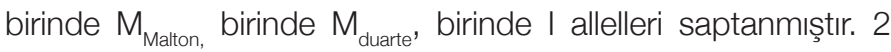
hastaya klinik ve karaciğer histopatolojisi ile tanı konulmuştur, fenotip veya genotiplendirme yapılamamıştır. Homozigot ZZ alleli ve diğer allellere sahip hastaların demografik özellikleri, başvuru ve muayene bulguları Tablo l'de gösterilmiştir.

Serum A1AT düzeyi, grup 1'de grup 2'ye göre istatistiksel olarak anlamlı düzeyde düşük bulunmuştur ( $p=0,016)$ (Tablo II). Transaminazlar, bilirübinler, gamma glutamil transferaz, alkalen fosfataz, albümin, protrombin zamanı, INR, hemoglobin, lökosit ve trombosit sayıları açısından iki grup arasında istatistiksel anlamlı fark bulunmamıştır ( $>>0,05)$ (Tablo II). Bir hastanın takibinde serum transaminazları normalin 3-4 katı olarak seyretmiş olup, diğer hastaların serum transaminazları normalin 1.5 katı artmış ya da normal aralıkta seyretmiştir. Transaminazları daha yüksek seyreden hastanın A1ATE açısından homozigot ZZ alleli olup, Alagille Sendromunun fenotipik bulguları görülse de moleküler incelemede JAG1 ve NOTCH2 genlerinde mutasyon saptanmamıştır. 
Tablo I: Başvuruda grup 1 ve 2'nin demografik ve klinik bulguları.

\begin{tabular}{|c|c|c|c|}
\hline & Grup 1 & Grup 2 & $\mathbf{p}$ \\
\hline Başvuru yaş, ay* & $10(3-30)$ & $12(1-66)$ & $>0.05$ \\
\hline Cinsiyet, erkek ${ }^{\dagger}$ & $5(71.4)$ & $9(69.2)$ & $>0.05$ \\
\hline Anne-baba arasında akrabalık ${ }^{\dagger}$ & $2(28.6)$ & $5(38.5)$ & $>0.05$ \\
\hline \multicolumn{4}{|l|}{ Başvuru bulguları } \\
\hline Kolestaz $^{\dagger}$ & $3(42.9)$ & $6(46.2)$ & $>0.05$ \\
\hline Asemptomatik transaminaz yüksekliği ${ }^{\dagger}$ & $4(57.1)$ & $7(53.8)$ & $>0.05$ \\
\hline Muayenede ikter ${ }^{\dagger}$ & $1(14.3)$ & $2(18.2)$ & $>0.05$ \\
\hline Muayenede hepatomegali $^{\dagger}$ & $5(71.4)$ & $8(61.5)$ & $>0.05$ \\
\hline Muayenede splenomegali ${ }^{\dagger}$ & $4(57.1)$ & $3(23.1)$ & $>0.05$ \\
\hline İzlem süresi, ay* & $68(1-108)$ & $6(2-127)$ & $>0.05$ \\
\hline
\end{tabular}

*Veriler ortanca (minimum-maksimum) olarak verilmiştir, $\boldsymbol{t}$ : $n(\%)$.

Tablo II. Hastalarımızın laboratuvar bulguları.

\begin{tabular}{|c|c|c|c|}
\hline & Grup 1 & Grup 2 & $\mathbf{p}$ \\
\hline AST, U/L & $114(68-148)$ & $85(34-343)$ & 0.415 \\
\hline ALT, U/L & $112(71-236)$ & $69(19-147)$ & 0.077 \\
\hline ALP, U/L & 470 (139-1592) & $209(33-1031)$ & 0.696 \\
\hline GGT, U/L & $60(13-2160)$ & $37(10-394)$ & 0.770 \\
\hline Total bilirübin, mg/dl & $0.5(0.2-10.7)$ & $0.7(0.1-9.9)$ & 0.733 \\
\hline Direkt bilirübin, mg/dl & $0.2(0.02-7.9)$ & $0.2(0.01-3.6)$ & 0.807 \\
\hline Albümin, g/dl & $4.6(3.3-5.1)$ & $4.2(3.2-4.7)$ & 0.383 \\
\hline PT, sn & $12.6(12.2-13.6)$ & $12(10.9-20.9)$ & 0.283 \\
\hline INR & $1.1(0.9-1.2)$ & $1(0.9-1.7)$ & 0.086 \\
\hline $\mathrm{Hb}, \mathrm{g} / \mathrm{dl}$ & $11.3(6.8-14.6)$ & $11.9(10.9-19.9)$ & 0.339 \\
\hline Lökosit, $\times 10^{3} / \mu \mathrm{l}$ & $12.3(9.1-22.7)$ & $10.5(7.7-18.1)$ & 0.421 \\
\hline Trombosit, $\times 10^{3} / \mu \mathrm{l}$ & $302(220-571)$ & $385(106-665)$ & 0.421 \\
\hline A1AT, mg/dl (N:90-200) & $34(27-66)$ & $75(22-91)$ & 0.016 \\
\hline
\end{tabular}

AST: aspartat aminotransferaz; ALT: alanin aminotransferaz; ALP: alkalen fosfataz; GGT: gamma glutamil transferaz; PT: protrombin zamanı; INR: international normalized ratio, A1AT: alfa-1 antitripsin.

Karaciğer biyopsisi yapılan 8 hastada orta-ağır fibrozis ve bu hastalardan 6'sında diastaz dirençli periyodik asid-schiff ile boyanan globüller görülmüștür. Alagille Sendromu fenotipini de tașiyan hasta ve $M Z$ alleline sahip hastada bu globüller izlenmemiștir. Bu hastalardan 2'sinde portal hipertansiyon bulguları da olup, izleminde karaciğer nakli yapılmıştır. Bu hastalardan MZ alleline sahip olana 5 yașında; histopatoloji ile tanı konulmuş olup fenotiplendirme çalışlamayan hastaya 15 yaşında karaciğer nakli yapılmıştır. Diğer 6 hastanın ortanca 8.75 ylllik (2.5-14.5 yll) izleminde portal hipertansiyon bulguları izlenmemiştir. Karaciğer biyopsisi yapılan hastalardan 5'i homozigot Z alleline, biri MZ alleline sahiptir. Diğer iki hasta histopatoloji ile tanı alan, fenotiplendirme yapılamayan hastalardır. Karaciğer nakli yapılan 2 hasta dışında, ortanca 3.25 yll (0.5-14.5) izlenen olgularımızın hepsine takip süresince ursodeoksikolik asit verilmiștir.

\section{TARTIŞMA}

A1ATE prevalansı yüksek olmasına rağmen, hastalığa sahip olanların \%10'unundan daha azının tanı aldığı düșünülmektedir (5). Nedeni belirlenemeyen karaciğer hastalığı ve ailede A1ATE yönünden karaciğer hastalığı olanlarda; tedaviye yanıtsız astım ve $\mathrm{KOAH}$ hastaları taranmalıdır (5). Uzamış sarılık ve kolestaz A1ATE'nin ilk 3 ayda görülen en sık başvuru bulgularıdır (1). Biliyer atrezide olduğu gibi akolik dıșkı görülebilir. Konjuge bilirübin düzeyleri ve transaminazlar hafif-orta derecede yükselir. Kolestaz bulguları 8 aya kadar uzayabilir (5). Hastalarımız, kolestaz ya da tesadüfen saptanan transaminaz yüksekliği nedeni araștırlırken A1AT düșüklüğü saptanarak, A1ATE tanısı almıșlardır. Çalıșmamızda 11 hasta (\%55) tesadüfen saptanmıș transaminaz yüksekliği ile, 9 hasta (\%45) kolestaz bulguları ile bașvurmuștur. Hastalarımızdan 3'ü (\%15), 2 ay ve altında sarılık yakınması ile başvurmuş olup, 2'sinde akolik dışkı 
görülmüştür. Başvuru yakınmalarının hem homozigot ZZ alleline sahip hem de diğer allellere sahip olgularda benzer oranlarda olduğu bulunmuştur. Homozigot $Z$ alleline sahip olgularda organomegali sıklığının diğer allellere sahip hastalara göre daha yüksek oranlarda olduğu görülse de istatistiksel olarak anlamlı bir fark saptanmamıştır.

A1ATE tanısının ilk basamağını A1AT serum düzeyinin ölçülmesi oluşturmaktadır. Akut faz reaktanı olması nedeni ile sistemik inflamasyon ve oral kontraseptif kullanımı ve gebelik gibi serum östrojen düzeylerinin arttığı durumlarda serumda A1AT düzeylerinin 3-5 kat artabileceği bilinmektedir $(5,8)$. Plazmadaki yarılanma ömrü yaklaşık 5 gündür (1). Birçok vücut sıvisında bulunur, birçok dokuya da geçer (1). Alt solunum yollarından alınan sıvı örneğinde, serumdaki konsantrasyonuna eşit miktarlarda bulunmaktadır (1). Protein kaybettiren enteropatilerde artmış enterosit yenilenme siklusu nedeniyle dışkı düzeyleri artar (1). Normal laboratuvar aralığının, alt sınııının \%50'sinden daha düşük düzeylerin tanısal olduğu kabul edilse de (5); duyarllık ve özgüllüğü düşük bulunduğundan normal serum düzeyleri A1ATE tanısını dışlatmamaktadır. (5). Homozigot Z alleli taşıyanlarda normal A1AT'in \%10-15'i, heterozigot MZ alleli taşıyanlarda ise \%50'si hepatositlerden dolaşıma salgılanır (5). Serimizde de homozigot $Z$ alleline sahip olguların serum A1AT düzeyinin diğer gruba göre daha düşük saptanmış olması bu durumu desteklemektedir. Hastalarımızdan 3'ünde A1AT düzeyi laboratuvarımıza göre normal aralığın alt sınııına yakın düzeyde (86-92 mg/dl) ölçülmüș olup, bu hastalardan 2'sinde MZ, bir hastada MS alleli saptanmıştır. Serum A1AT düzeyinin normal değeri 150 mg/dl olarak alındığında; heterozigot MZ alleli olan olgularımııın normalin \%46.6'sı, homozigot Z alleli olanların \%27.6'sı kadar serum A1AT düzeylerine sahip olduğu görülmektedir.

Fenotipleme analizinde izoelektrik fokuslama yöntemi ile anormal A1AT proteinleri ayrıştırlır. Sık görülen $Z$ ve $S$ mutasyonları ayırt edilebilir. Homozigot disfonksiyonel veya heterozigot disfonksiyonel ve null allellerde ise, sadece fonksiyon bozukluğu olması nedeni ile fenotipleme kullanılamaz (5). Karaciğer tutulumu ile izlediğimiz A1ATE olan çocuk hastalarımızda \%35 oranında homozigot Z alleli, \%35 oranında heterozigot MZ alleli, \%15 oranında diğer alleller saptanmıştır. İki hastaya karaciğer histopatolojisi ve klinik bulgularla tanı konmuştur. Homozigot Z alleli, karaciğer hastalığı için bir risk faktörü olmasına rağmen, bu mutasyona sahip hastaların sadece \%50'sinde karaciğer fonksiyonlarında bozukluk ve \%10-20'sinde klinik olarak belirgin karaciğer hastalığı görüldüğü bildirilmiştir $(5,9) .18$ yaşından önce hastaların \%5'inde siroz veya son dönem karaciğer hastalığı görülmektedir (5).

Heterozigot Z alleli, genotip $M Z$ allelinin karaciğer hastalığı açısından risk faktörü olduğu tartışmalıdır (10). Heterozigot MZ alleli taşımanın, çocuklarda karaciğer hastalı̆ına yol açtığına dair kanıt yoktur (1). Türkiye'de yapılan bir çalışmada da homozigot $Z$ alleli olanların çoğunda kronik karaciğer hastalığı görülmüş, heterozigot $M Z$ allelinde ise izlemde normale dönen asemptomatik transaminaz yüksekliği görülmüştür (11). Çalışmamızda 7 hasta heterozigot MZ alleline sahip olup, sadece bir tanesine karaciğer nakli yapılmıştır. Diğer hastalarda asemptomatik transaminaz yüksekliği görülmüştür. Erişkin siroz hastalarında yapılan bir vaka-kontrol çalişmasında, homozigot Z allelinin siroz ile ilişkili, ancak heterozigot $Z$ allellerinin (MZ ve SZ gibi) ilişkisi olmadığı gösterilmiştir (10). Erişkinlerde ise kriptojenik siroz ve karaciğer nakli olan hastalarda heterozigot A1ATE hastalarının prevalansının yüksek bulunduğu bildirilmektedir (12). Homozigot SS alleli ile hepatositlerden dolaşıma, normal A1AT'in \%52'si, heterozigot SZ alleli ile normal A1AT'in \%32'si, heterozigot MS alleli ile \%75'i salgılanır (5). Heterozigot ZS alleli olan çocuklarda ZZ benzeri karaciğer hasarı tanımlanmışıı (1). $S$ mutant proteini karaciğerde birikir ancak, Z mutant proteini ile birlikte olmadığı sürece intrahepatik toksik polimerler oluşmaz (7). Bu nedenle homozigot SS allelinde karaciğer tutulumu olmaz iken heterozigot SZ allelinde görülebilir (7). Hastalarımızdan birinde MS alleli saptanmış olup, 15 günlük iken transaminaz yüksekliği ile başvurmuştur, A1AT düzeyi normal aralığın alt sınıına yakın 86 mg/dl ölçülmüştür (normal aralık: 90-200). Hastanın serum transaminaz düzeyleri 2 ay sonra normal aralıkta saptanmıştır. Hasta 4 yildır izlenmekte olup serum transaminaz düzeyleri normal aralıkta seyretmiştir. $M_{\text {Maltonn }}, M_{\text {Duarte }}, W, F Z$, King's gibi birçok allelik A1AT varyantında karaciğer hastalığı tanımlanmıştır (1). Hastalarımızdan birinde $\mathrm{M}_{\text {Maton, }}$, birinde $\mathrm{M}_{\text {Duarte' }}$, birinde I allelleri saptanmıştır. $M_{\text {Duarte }}$ alleli olan hasta hipoglisemi ve laktik asidoz bulguları ile birlikte genetik olarak glikojen depo hastalığı tip 0 tanısı almış olup serum transaminaz düzeyleri normal aralıktadır. $\mathrm{M}_{\text {Malton }}$ alleli olan hastanın serum transaminaz düzeyleri 1-1.5 kat yüksek seyretmektedir. I alleli olan hastanın serum transaminaz düzeyleri normal aralıkta seyretmektedir.

Null alleller ile plazmada A1AT saptanmaz, Pi yerine Q0 olarak belirtilir (5). İki null allel ya da bir null, bir eksiklik alleli olduğunda premature amfizem görülür (1). Bu alleller nadir görülürler, beyaz ırkta \%0.1'in altında görülmektedir; protein salgllanmaz, polimerik yapı da oluşmaz, akciğer bulguları ağır seyirlidir (5). Disfonksiyonel AAT varyantlarında protein fonksiyonu değișmiştir, plazmada normal miktarlarda A1AT sentezlenir. A1AT fonksiyonel olarak aktif olup, spesifik olarak elastaz inhibitor kapasitesinde de düşüklük olabilir (1).

Karaciğer tutulumu olan A1ATE olgularında karaciğer tutulumunun özgül bir tedavisi yoktur (1). Kanıt düzeyi yeterli olmasa da ursodeoksikolik asit ve kolșisin tedavide önerilen ilaçlardır (1). Bizim hastalarımızın hepsinde ursodeoksikolik asit kullanımışıtır. Karaciğer yetmezliği ve ilerleyici karaciğer disfonksiyonu olan hastalarda karaciğer nakli yapılmakta olup, 5 yıllık yaşam beklenti oranı \%92'dir (1). Tedavide amaç, A1AT'in hepatositte polimerizasyonunu engellemek ve sonrasında gen tedavisi olmalıdır. Ağır akciğer hasarı oluşmadan karaciğer nakli de tedavi seçenekleri arasındadır (5). Serumda düşük A1AT düzeylerinin karaciğer hasarı ile ilişkisi olmadığı için protein replasman tedavisi karaciğer hastaları için önerilmez (1). Polimerizasyonu engellemek, katlanma hatasını düzeltmek için 
şaperonlara benzer (kimyasal şaperonlar) gliserol, trimetilamin $\mathrm{N}$-oksid ve üre siklus defektlerinde kullanılan 4-fenilbütirik asid (PBA), suberoilanilid hidroksamik asid (SAHA); karaciğerdeki A1AT yükünü azalttığı ve fibrozisi azalttığı gösterilen karbamazepin; anormal katlanmış A1AT üretimini azalttığı gösterilen RNAi (C. elegans modeli) bazlı terapötikler (trisiklik antidepresanlara yapısal benzeyen ilaçlar ve fenotiazin grubu ilaçlar) ile ilgili bir çok deneysel çalışmalar yapılmaktadır $(1,5,13)$. Gen ve kök hücre tedavileri ve hepatosit nakli de etkin tedavi seçenekleridir (5).

A1ATE çocuklarda karaciğer hastalığının önemli bir nedeni olsa da bu mutasyonu taşıyan hastaların az bir kısmında ilerleyici karaciğer hastalığı gelişmektedir. Sınırı sayıda hasta ile yapılan bu çalışmada literatüre benzer șekilde homozigot $Z$ alleli varlığının daha düşük serum A1AT düzeyleri ve daha şiddetli karaciğer tutulumu ile ilişkili olduğu görülmüştür. A1ATE diğer ülkelerde sık görülen bir genetik hastallk olmasına rağmen, akraba evliliği sıklı̆ının oldukça yüksek olduğu ülkemizde diğer genetik karaciğer hastalıklarına göre daha nadir görüldüğü düşünülmektedir. Allel sıklığı, klinik bulguları ve seyrini değerlendirebilmek için ülkemizden A1ATE ile ilgili çok merkezli daha fazla çalısmaya gereksinim duyulmaktadır.

\section{Finansal Kaynak}

Bu çalışma sırasında, yapılan araştırma konusu ile ilgili doğrudan bağlantısı bulunan herhangi bir ilaç firmasından, tıbbi alet, gereç ve malzeme sağlayan ve/veya üreten bir firma veya herhangi bir ticari firmadan, çalışmanın değerlendirme sürecinde, çalısma ile ilgili verilecek kararı olumsuz etkileyebilecek maddi ve/veya manevi herhangi bir destek alınmamıştır.

\section{Çıkar Çatışması}

Bu çalışma ile ilgili olarak yazarların ve/veya aile bireylerinin çıkar çatışması potansiyeli olabilecek bilimsel ve tıbbi komite üyeliği veya üyeleri ile ilişkisi, danışmanlık, bilirkişilik, herhangi bir firmada çalışma durumu, hissedarlık ve benzer durumları yoktur.

\section{KAYNAKLAR}

1. Perlmutter DH. Genetic and Metabolic Disorders, Alpha-1 Antitrypsin Deficiency. in: Kleinman RE, Goulet OJ, Mieli-Vergani G, Sanderson IR, Sherman PM, Shneider BL editors. Walker's Pediatric Gastrointestinal Disease 6th ed. North Carolina: People's Medical Publishing House-USA 2018:3825-87.

2. de Serres FJ. Alpha-1 antitrypsin deficiency is not a rare disease but a disease that is rarely diagnosed. Environ Health Perspect 2003;111:1851-4.

3. Basturk A, Yılmaz A, Sayar E, Dinçhan A, Aliosmanoğlu I, Erbiş H et al. Pediatric Liver Transplantation: Our Experiences. Eurasian J Med 2016;48:209-12.

4. Moray G, Tezcaner T, Akdur A, Özçay F, Sezgin A, Kırnap M, et al. Results of pediatric liver transplant: a single-center experience. Exp Clin Transplant 2015 Apr;13 Suppl 1:59-63.

5. Hazari YM, Bashir A, Habib M, Bashir S, Habib H, Qasim MA. Alpha1-antitrypsin deficiency: Genetic variations, clinical manifestations and therapeutic interventions. Mutat Res 2017;773:14-25.

6. Townsend SA, Edgar RG, Ellis PR, Kantas D, Newsome PN, Turner AM. Systematic review: the natural history of alpha- 1 antitrypsin deficiency, and associated liver disease. Aliment Pharmacol Ther 2018;47:877-85.

7. Teckman J. Author's response. J Pediatr Gastroenterol Nutr 2015;60:e38

8. Abboud RT, Nelson TN, Jung B, Mattman A. Alpha1-antitrypsin deficiency: a clinical-genetic overview. Appl Clin Genet 2011 Mar 31;4:55-65.

9. Bjursell M, Porritt MJ, Ericson E, Taheri-Ghahfarokhi A1, Clausen M1, Magnusson L. Therapeutic Genome Editing With CRISPR/ Cas9 in a Humanized Mouse Model Ameliorates a1-antitrypsin Deficiency Phenotype. EBioMedicine 2018;29:104-11.

10. Schaefer B, Mandorfer M, Viveiros A, Finkenstedt A, Ferenci P, Schneeberger $S$, et al. Heterozygosity for the alpha-1-antitrypsin Z allele in cirrhosis is associated with more advanced disease. Liver Transpl 2018;24:744-51.

11. Comba A, Demirbaş F, Çaltepe G, Eren E, Kalayci AG. Retrospective analysis of children with a-1 antitrypsin deficiency. Eur J Gastroenterol Hepatol 2018;30:774-8.

12. Cacciottolo TM, Gelson WT, Maguire G, Davies SE, Griffiths WJ. $P{ }^{\star} Z$ heterozygous alpha- 1 antitrypsin states accelerate parenchymal but not biliary cirrhosis. Eur J Gastroenterol Hepatol 2014;26:412-7.

13. Turner AM, Stolk J, Bals R, Lickliter JD, Hamilton J, Christianson $\mathrm{DR}$, et al. Hepatic-targeted RNAinterference provides robust and persistent knockdown of alpha-1 antitrypsin levels in ZZ patients. J Hepatol 2018;69:378-84. 